\title{
Contribution of geophysics to geometric characterization of freshwater-saltwater interface in the Maâmoura region (NE Tunisia)
}

\author{
Achref Chabaane ${ }^{1,2} \cdot$ Belgacem Redhaounia $^{1} \cdot$ Hakim Gabtni $^{1} \cdot$ Adnen Amiri $^{3}$
}

Received: 4 July 2017 / Accepted: 16 May 2018 / Published online: 12 July 2018

(c) The Author(s) 2018

\begin{abstract}
The Maâmoura aquifer is located on the eastern coast of the Cap Bon peninsula. During recent decades, the agricultural exploitation of water has been strongly reinforced, causing an over-pumping of the groundwater resources accompanied by an intrusion of seawater. The geophysical approach based on electrical resistivity tomography has been adopted to obtain high-resolution electrical sections imaging, which allows delineatation of the areas characterized by a high salinization and reconstructs the geometry of the saline wedge front. In fact, the presence of seawater in the aquifers reduces subsurface resistivity values. In this study, five electrical profiles were performed using the Terrameter SAS4000 Lund Imaging System with an array of 64 electrodes. The Wenner configuration was used with a unit electrodes spacing of $5 \mathrm{~m}$. Finally, we use hydrogeological data, and electrical resistivity tomography data superimposed with the location of wells to provide a conceptual framework for the understanding of the freshwater-saltwater interface in the Maâmoura region.
\end{abstract}

Keywords Salinization $\cdot$ Electrical resistivity tomography $\cdot$ Freshwater-saltwater interface $\cdot$ Maâmoura $\cdot$ Tunisia

\section{Introduction}

The salinization of coastal aquifers is a major hydrogeological risk affecting coastal or island regions, mainly those situated in the semi-arid area (Tunisia, Algeria, Morocco, Egypt, etc.) (Bouchaou et al. 2005; Zouhri et al. 2008; Paniconi et al. 2001; Kerrou 2008; Tarhouni et al. 2002; El Gayar and Hamed 2017; Hamed et al. 2018).

The eastern coast of Cap Bon peninsula, which is located in the northeastern part of Tunisia (Fig. 1a), is known as one

Achref Chabaane

chabaaneachref@gmail.com

Belgacem Redhaounia

belgacem.redhaounia@yahoo.fr

Hakim Gabtni

gabtni_hakim@yahoo.ca

Adnen Amiri

adnen.amiri@gmail.com

1 Water Researches and Technologies Center Borj-Cedria (CERTE), BO 273, 8020 Soliman, Tunisia

2 Faculty of Sciences of Bizerte, University of Carthage, 7021 Bizerte, Tunisia

3 Faculty of Sciences of Tunis, University of Tunis El Manar, 2092 Tunis, Tunisia of the most agriculturally productive zones in the country, and there has been an increase in population and industrial/ tourist activities as in any other part of Tunisia. This increase is directly associated with a high water demand (Tarhouni et al. 2000; Omrane 2008). This demand is ensured almost by the only resource available, which is groundwater through a number of wells that does not cease to increase. This overexploitation has significantly affected water quality mainly through marine intrusion and has resulted in the abandonment of wells that are close to the sea coast. In addition, industrial and domestic discharges, and also the use of pesticides and chemical fertilizers in this area has significantly affected the quality of water (Daskalaki and Voudouris 2008; Kazakis et al. 2016; Giambastiani et al. 2013; Fadili et al. 2015; Najib et al. 2016, 2017; Besser et al. 2017; Ben Alaya et al. 2009; El Mandour et al. 2007; Lambrakis et al. 1997; Ferrara and Pappalardo 2004).

Previous studies dealing with the groundwater salinization process in the study area (Chekirbane et al. 2013; Lecca et al. 1998; Paniconi et al. 2001; Gaaloul and Cheng 2003; Kouzana et al. 2009; Gaaloul et al. 2012; Mekni and Souissi 2016) confirms the presence of seawater intrusion. But the limit between freshwater and saltwater has not been developed in these studies. For this purpose, electrical resistivity tomography is a particularly pertinent geophysical method 
Fig. 1 a Geographical location of study area. b General geological map of the Maâmoura study area extracted from 1/50,000 geological maps of Nabeul (Ben Salem, 1995). c Positioning plan of ERT profiles 3, 4 and 5. d Positioning plan of ERT profiles 1 and 2

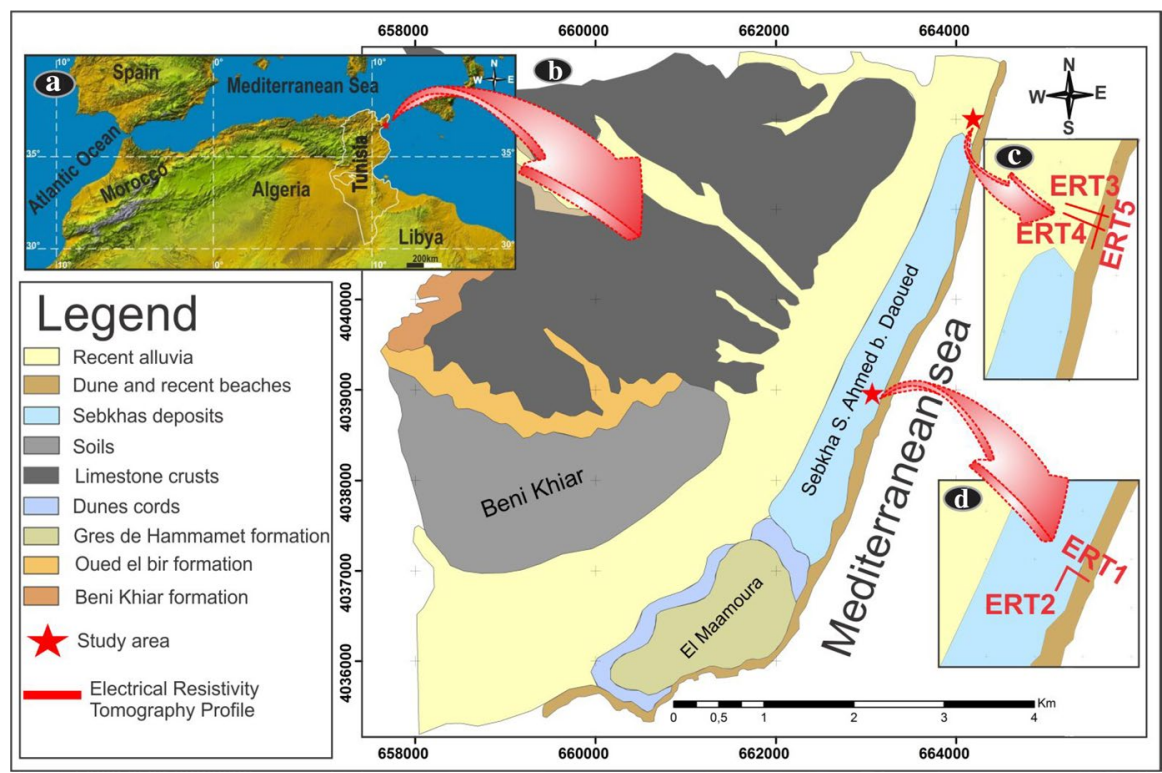

since it provides valuable geological and structural information and a relatively precise geometry imagery of the seawater/freshwater interface (Zghibi et al. 2013; Kouzana et al. 2010).

The objective of this paper is to determinate precisely the limit between freshwater and saltwater and the geometry of seawater plume.

\section{Geological setting}

The outcropping formations in the study area are mainly Mio-Plio-Quaternary deposits (Fig. 1b) (Ben Salem 1995). The local lithostratigraphic series corresponds from top to bottom to:

- Quaternary deposits: formed by recent alluvia, limestone crusts, dune and recent beaches, Sebkhas deposits, dune cords, and soils; the dune cords are formed by a superposition of sandstones and limestones levels, the limestone crust is composed by a relatively thick carbonate crust covering almost all the coastal plateaus (Colleuil 1976; Ben Salem 1992).

- Lower and middle Pliocene outcrops do not exist in the study area and the upper Pliocene is presented by "Grès de Hammamet" formation. These deposits are mainly composed by fine sand sometimes clayey and containing sandy levels. The Pliocene formations outcrop generally in the Maâmoura region (Ennabli 1980).

- The Upper Miocene corresponds in its lower part to the "Beni Khiar" formation, and its upper part is formed by the "Oued El Bir" formation. The Beni Khiar formation outcrop in the Beni Khiar region and it is composed gen- erally of sandstones, sands and a limestone level. This formation has a thickness less than $20 \mathrm{~m}$. The Oued El Bir formation is presented by dominance of sandstones with intercalations of clayey and sandy levels, and showing a thickness of average $100 \mathrm{~m}$ (Ben Salem 1995).

\section{Hydrogeology}

The regional hydrogeology of the eastern coastal aquifer of Cap Bon has been studied by various previous researchers (Ennabli 1980; Paniconi et al. 2001; Kouzana et al. 2010; Zghibi et al. 2011) showing that the aquifer system is layered:

The first aquifer formed by Plio-Quaternary deposits and a second aquifer formed by Miocene deposits; the PlioQuaternary detrital deposits of eroded products from Djebel Sidi Abderrahmen anticline and Dakhla syncline constitute a potential shallow aquifer. The marls of the Middle Miocene form the impermeable substratum of this aquifer (Ennabli 1980; Paniconi et al. 2001; Kouzana et al. 2010; Zghibi et al. 2011).

The Miocene aquifer is formed by sandstone bars with different thickness and lateral variation, this aquifer have a considerable water resources (Zghibi et al. 2011).

The pumped waters of Quaternary aquifers have been used generally in the field of agriculture since the 1960s. Because of the strong exploitation of the aquifer, this reached 135\% in 2004 (Paniconi et al. 2001; Zghibi et al. 2011). The seawater began to penetrate into coastal land. As a result, several geophysical and geochemical studies have highlighted the invasion of seawater in coastal areas 
(Kouzana et al. 2009, 2010; Chekirbane et al. 2013; Zghibi et al. 2013).

\section{Material and method}

ERT and IP methods are electrical techniques that provide detailed information of the subsurface resistivity and induced polarization distribution. Electrical resistivity tomography (ERT) is a geophysical approach based on resistivity contrast, used to determine earth resistivity distribution on the sub-surface. Because of the large electrical resistivity contrast between seawater $(0.2 \Omega \mathrm{m})$ (Nowroozi et al. 1999) and freshwater (>10 $\Omega \mathrm{m})$; resistivity methods make it possible to map the subsurface groundwater salinity distribution (Maillet et al. 2005; Batayneh 2006; Martinez et al. 2009; Mario et al. 2011; Zarroca et al. 2011; Rey et al. 2013; Werner et al. 2013; Eissa et al. 2016; Kazakis et al. 2016; Goebel et al. 2017; Najib et al. 2017).

The induced polarization (IP) is an electrical method, which measures chargeability by the voltage decay over a specified time interval after the removal of the artificial current. The voltage does not return to zero instantaneously and decays slowly, indicating that charge has been stored in the rocks. In simple terms, the IP effect reflects the degree to which the rock/soil can store electric charge when an electric current passes through it in a manner analogous to a leak capacitor (Dobrin Lise 1998; Kiberu, 2002; MartinezMoreno et al. 2013; Chabaane et al. 2017a; Besser et al. 2017; Tkachev et al. 2017).

In the present study, the electrical resistivity tomography campaign was carried out in order to detect the salt water depth and its lateral extension. Five electrical resistivity tomography (ERT) profiles and two induced polarization (IP) profiles were produced near the coast (Fig. 1b); two profiles were located at the east of the sebkha (Fig. 1d) and three beyond the Daroufa wadi (Fig. 1c). In the first site, two profiles were carried out; the first profile (ERT 1\& IP 1) was placed perpendicular to the coastline and the second one (ERT 2 \& IP 2) was placed parallel to the coastline. In the second site, three profiles were carried out in order to cover the whole study area; two were placed perpendicular to the coastline (ERT 3 and ERT 4) and the other one was placed parallel to the coast (ERT 5). ERT imaging surveys were conducted using an ABEM Terrameter LUND Imaging System and a SAS 4000 resistivity instrument (Fig. 2c).

The resolution of 2D profiles depends on arrays used, as well as spacing between electrodes placed on the ground. Several configurations are available for the electrodes arrays such as Schlumberger, Wenner, dipole-dipole or pole-dipole. Each protocol has its own characteristics in terms of depth of investigation, lateral and vertical resolution, horizontal coverage or signal length (Dahlin and Loke

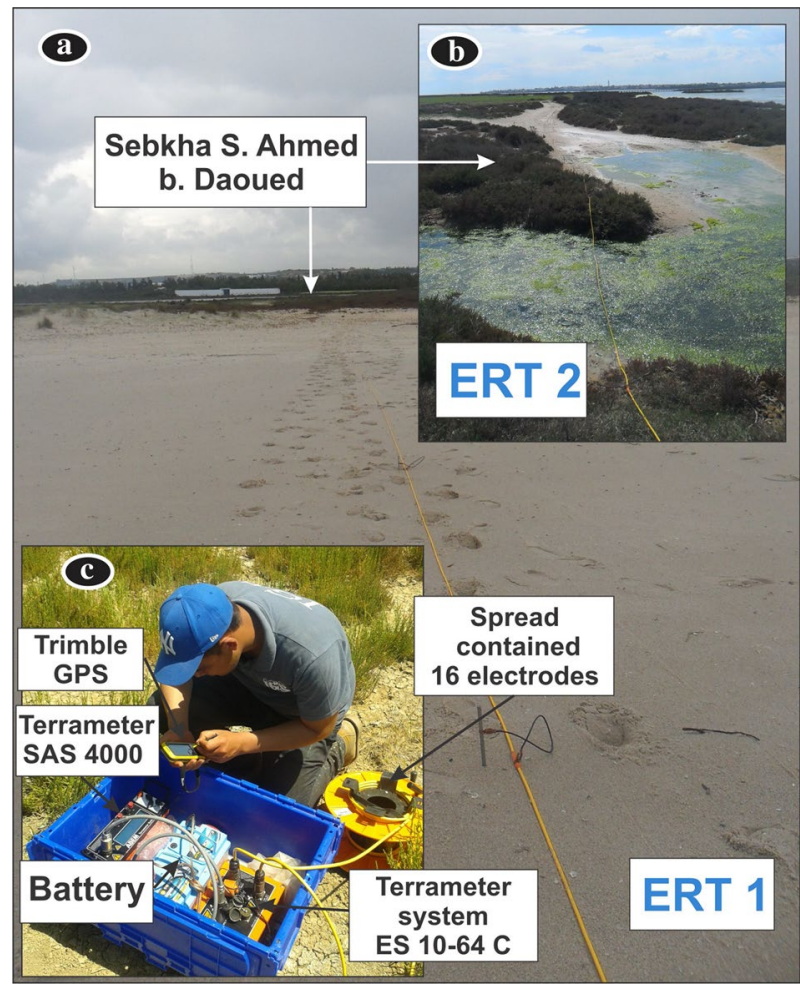

Fig. 2 a-b Photos showing ERT 1 and ERT 2. c Photo showing the geophysical equipment: ABEM SAS-4000 for ERT surveys

1998). The Wenner array was used, due to its stronger signal-to-noise ratio and its high resolution on detecting salt water plume (Mcinnis et al. 2013; Sauret et al. 2015; Redhaounia et al. 2016; Chabaane et al. 2017b). In this study, the electrode spacing was set as $5 \mathrm{~m}$, and 32 electrodes were used for ERT 1, ERT 2 and ERT 5 and 48 electrodes for ERT 3 and ERT 4.

ERT data were processed using the inverse modeling program RES2DINV (Geotomo Software) (Loke and Barker 1996) to provide estimates of the two-dimensional spatial distribution of resistivity along the survey profile. The inversion algorithm is based on the standard smoothness-constrained least-squares inversion algorithm (Gauss-Newton method) (De Groot-Hedlin and Constable, 1990; Sasaki, 1992). The 2D inversion results were obtained with a RMS error less than $3 \%$ and a number of iteration which various from three to six iterations, the low RMS values reflects the high data quality. Topography was not corrected because of the flatness of the study area.

\section{Geophysical interpretation}

The geophysical interpretation is described and discussed using the results obtained at the two sites, the geological data and data from deep wells. 
The first ERT profile was carried out perpendicular to the coast in order to detect the saline plume (Fig. 2a). Inverted model presents an average RMS error of $2.7 \%$ indicating a good quality of the obtained result. This profile shows very low resistivities, which vary between 0.6 and $2.3 \Omega \mathrm{m}$. These values correspond perfectly to the seawater plume, which generally has resistivity values ranging between 0.2 and $1 \Omega \mathrm{m}$. So through this profile, we can clearly detect the saline plume that exceeds $22 \mathrm{~m}$ depth, and the invasion of this coastal zone by marine waters (Fig. 3).

The second electrical profile was made parallel to the coast with $155 \mathrm{~m}$ length and perpendicular to the first profile (Fig. 2b). This profile shows an average RMS error of $1.9 \%$ suggesting the obtained results accuracy. From the electrical characteristics point of view, there is no difference between the two 2D models with resistivities ranging between 0.46 and $2.23 \Omega \mathrm{m}$. This model also detects the seawater plumes along the section. We can notice that this model shows the transverse shape of a marine intrusion (Fig. 4).

IP 1 and IP 2 are carried out respectively at ERT 1 and ERT 2 profiles, with the same electrode number and electrode spacing. The IP models resulting from $2 \mathrm{D}$ numerical inversions are presented in Figs. 5 and 6. It can be pointed out that there exists a conductive zone having the lowest chargeability value less than $1 \mathrm{~ms}$. That conductive zone is predicted as the plume of seawater, this is confirmed by ERT 1 and ERT 2, which shows low resistivities in the zones having low chargeability. For the zones with highest values of chargeability (more than $1 \mathrm{~ms}$ ), they correspond generally to clay deposits.

In the first site, ERT 1, ERT 2, IP 1 and IP 2 profiles show the response of the coastal dunes to the subsurface, and that these sands are encroached by seawater.

The third profile was carried out perpendicular to the coast with $235 \mathrm{~m}$ length, and in the north of the Daroufa wadi. This profile shows an average RMS error of $1.1 \%$ indicating good quality of the ERT results, resistivity values vary from 0.28 to $11.21 \Omega \mathrm{m}$. We notice the presence of seawater characterized by its low resistivity (less than $1 \Omega \mathrm{m}$ ). In this zone the seawater has entered and has salinized the groundwater. This phenomenon is confirmed by the data of the deep well placed in the center of the ERT profile and having $120 \mathrm{~m}$ depth and which has captured highly salted water. We also note the presence of some freshwater lentils
Fig. 3 Inverse model resistivity section for survey geo-electrical profile number 1 , with 5 -m electrode spacing, 32 electrodes

Fig. 4 Inverse model resistivity section for survey geo-electrical profile number 2 , with 5-m electrode spacing, 32 electrodes
Fig. 5 Inverse model chargeability section for induced polarization profile number 1 , with 5-m electrode spacing, 32 electrodes
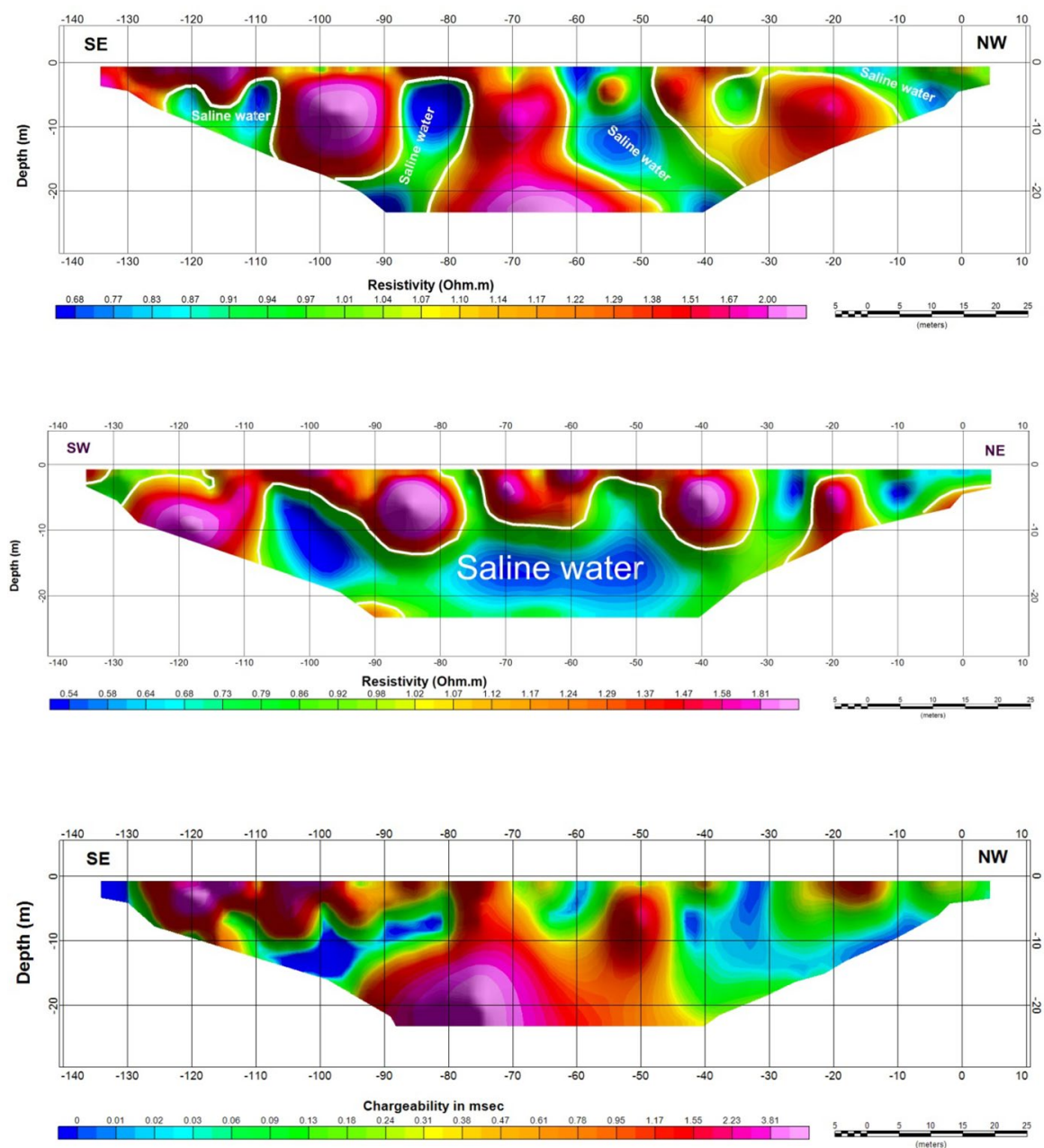
whose resistivity is near $10 \Omega \mathrm{m}$. The saltwater plumes and freshwater lentils are separated by transition zones of a few meters (Fig. 7).

The fourth profile was made in the south of the Daroufa wadi with $235 \mathrm{~m}$ length. The inverted model presents an average RMS error of $2.8 \%$ indicating a good quality of the obtained result, this profile shows resistivity values ranging between 0.2 and $15 \Omega \mathrm{m}$. The low resistivities (average $0.2 \Omega \mathrm{m}$ ) correspond perfectly to the seawater plume; this plume reaches $30-\mathrm{m}$ depth on the center of the inverted model and $25 \mathrm{~m}$ in the eastern part of the profile. In the center and the west of the profile a lens of freshwater was observed, these lenses reaches 20-m depth and was captured by a surface well. In this profile the transition zone (between freshwater and seawater) was perfectly observed. In addition, other secondary plumes of freshwater and seawater are detected in this model (Fig. 8).

The fifth ERT profile was executed perpendicular to the Daroufa wadi, ERT 3 and ERT 4 profiles, with $140 \mathrm{~m}$ length. In the northern part, this profile was placed partly on Daroufa wadi. ERT 5 model shows an average RMS error of $1.1 \%$ indicating good quality of the obtained results. The resistivity values vary between 0.3 and $6 \Omega \mathrm{m}$. For the northern part of the profile, it can be seen that this part shows the lowest resistivity values $(<0.5 \Omega \mathrm{m})$. This anomaly corresponds to seawater. The marine intrusion detected at this level is favored by the wadi, so it can be said that the outlet of the wadi favors the infiltration of seawater and facilitates its infiltration towards the aquifer (Fig. 9).

Overall, by comparing the results of the two studied sites, the profiles made near the Maâmoura city show a dominance of saltwater plumes and, therefore, a high contamination by seawater. In the second site seawater, freshwater and transition zones are found. In addition to the overexploitation of the groundwater, the extrados faults also affect the fractured "pop-up" structure of Korba (Adouani and Aissaoui 2003) and have created zones of weakness allowing canalizing seawater.

\section{Conclusions and perspectives}

In this study, use of the electrical resistivity tomography (ERT) provides new knowledge of freshwater and saltwater in the El Maâmoura Region.
Fig. 6 Inverse model chargeability section for induced polarization profile number 2 , with 5-m electrode spacing, 32 electrodes

Fig. 7 Inverse model resistivity section for survey geo-electrical profile number 3 , with 5-m electrode spacing, 48 electrodes

Fig. 8 Inverse model resistivity section for survey geo-electrical profile number 4 , with 5-m electrode spacing, 48 electrodes
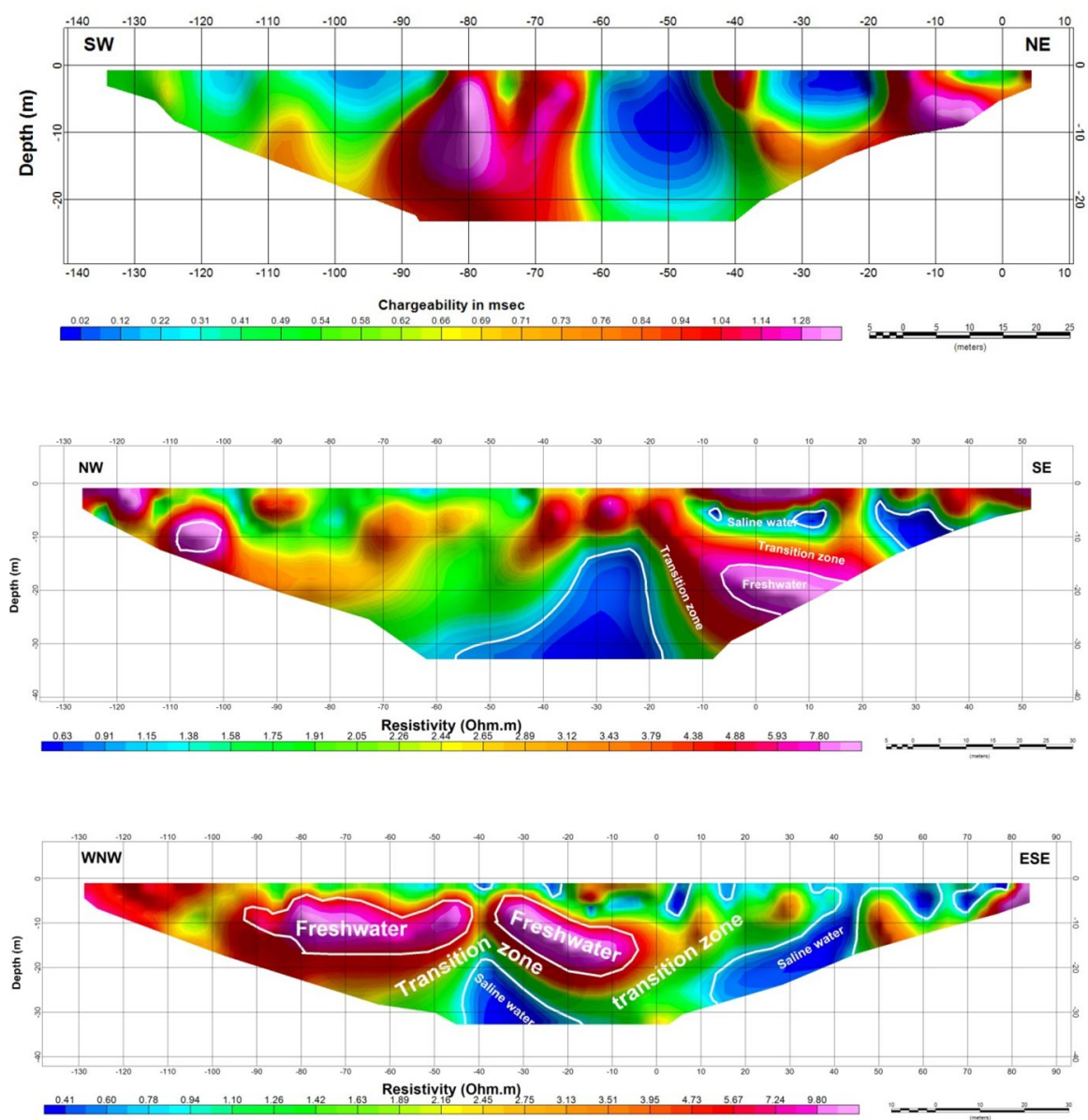
Fig. 9 Inverse model resistivity section for survey geo-electrical profile number 5 with electrode spacing is $5-\mathrm{m}, 32$ electrodes

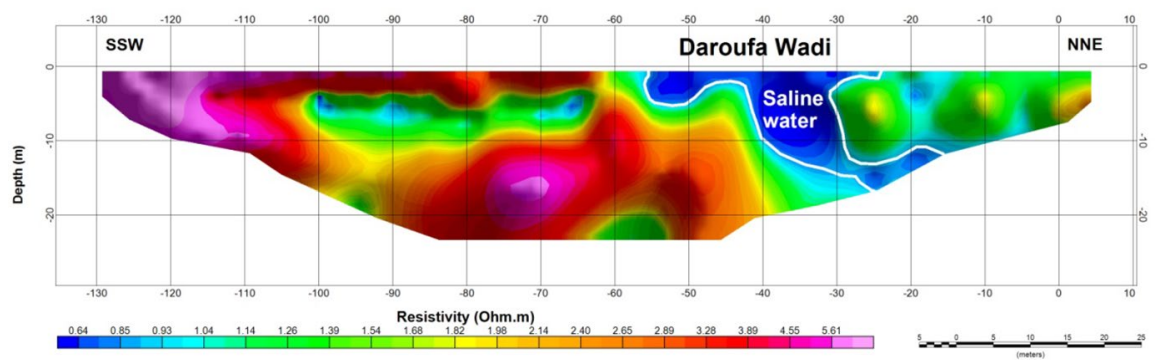

The results of the study show that the high resolution and sensitivity to the gradient separating are very much controlled by the spatial distribution of the freshwater and saltwater of the seawater intrusion. The compilation of the geological and geo-electrical methods (ERT and IP) provided greater confidence in the inferred results.

In the sector, combining of hydrogeological and geo-electrical investigation (ERT and IP) provides valuable information of the studied sites, the distribution and architecture of seawater and freshwater plumes, and the determination of the contact between these plumes.

Finally, it is thought that further studies (electromagnetic, microgravity and ERT) are required to detect and understand the most affected areas by seawater intrusion in the NE Tunisia.

Acknowledgements The research was supported by Water Researches and Technologies Center Borj-Cedria (CERTE, Tunisia). Gratitude is also addressed to reviewers for their criticism and suggestions conducting to the implementation and improvement of the final version of the manuscript.

\section{Compliance with ethical standards}

Conflict of interest We declare that there are no conflicts of interest associated with this manuscript.

Open Access This article is distributed under the terms of the Creative Commons Attribution 4.0 International License (http://creativeco mmons.org/licenses/by/4.0/), which permits unrestricted use, distribution, and reproduction in any medium, provided you give appropriate credit to the original author(s) and the source, provide a link to the Creative Commons license, and indicate if changes were made.

\section{References}

Adouani F, Aissaoui S (2003) Chronologie des évènements tectoniques et implication pétrolière dans la région cap-bon Grombalia. In: 1ère Journée des Jeunes Géologue

Batayneh A (2006) Use of electrical resistivity methods for detecting subsurface fresh and saline water and delineating their interfacial configuration: a case study of the eastern dead sea coastal aquifers. Jordan J Hydrogeol 14:1277-1283. https://doi.org/10.1007/s1004 0-006-0034-3

Ben Alaya A, Chkirbene A, Jallali S, Harbaoui K, Tarhouni J (2009) Evaluation de la qualité des eaux de la nappe de la côte orientale du Cap-Bon en Tunisie. Symposium international «agriculture durable en région méditerranéenne (AGDUMED). Rabat, Maroc, pp 1-9

Ben Salem H (1992) Contribution à la connaissance de la géologie du Cap Bon: stratigraphie, tectonique et sédimentologie. Thesis $(\mathrm{PhD})$, Faculty of Sciences of Tunis, Tunisia

Ben Salem H (1995) Notice explicative de la carte géologique de la Tunisie à 1/50.000 Nabeul-Hammamet Feuille n 30\&37, 32 p

Besser H, Mokadem N, Redhouania B, Rhimi N, Khlifi F, Ayadi Y, Omar Z, Bouajila A (2017) Hamed Y (2017) GIS-based evaluation of groundwater quality and estimation of soil salinization and land degradation risks in an arid Mediterranean site (SW Tunisia). Arab J Geosci 10:350. https://doi.org/10.1007/s1251 7-017-3148-0

Bouchaou L, Hsissou Y, Krimissa M, Krimissa S, Mudry J (2005) $2 \mathrm{H}$ and $18 \mathrm{O}$ isotopic study of ground waters under a semi-arid climate. In: Lichtfouse E, Schwarzbauer J, Robert D (eds) Environmental geochemistry, green chemistry and pollutants in ecosystems. Springer XXVI, New York, pp 57-64

Chabaane A, Redhaounia B, Gabtni H (2017a) Combined application of vertical electrical sounding and $2 \mathrm{D}$ electrical resistivity imaging for geothermal groundwater characterization: hammam Sayala hot spring case study (NW Tunisia). J Afr Earth Sc 134:292-298

Chabaane A, Redhaounia B, Gabtni H, Amiri A (2017b) Contribution of geophysics to geometric characterization freshwatersaltwater interface in the Maâmoura region. (NE Tunisia). P38

Chekirbane A, Tsujimura M, Kawachi A, Isoda H, Tarhouni J, Benalaya A (2013) Hydrogeochemistry and groundwater salinization in an ephemeral coastal flood plain: Cap Bon, Tunisia. Hydrol Sci J 58(5):1097-1110

Colleuil B (1976) Étude stratigraphique et néotectonique des formations néogènes et quaternaires de la région Nabeul-Hammamet (Cap Bon, Tunisie). Thesis (PhD), University of Nice, France

Dahlin T, Loke MH (1998) Resolution of 2D Wenner resistivity imaging as assessed by numerical modeling. J Appl Geophys 38(4):237-249

Daskalaki P, Voudouris K (2008) Groundwater quality of porous aquifers in Greece: a synoptic review. Environ Geol 54:505-513

De Groot-Hedlin C, Constable S (1990) Occam's inversion to generate smooth, two dimensional models from magneto telluric data. Geophysics 55:1613-1624

Dobrin Lise M (1998) The morphological reality of phonological form. In: Booij, Geert, van Marle, Jaap (Eds.), Yearbook of Morphology, p 59-68

Eissa MA, Mahmoud HH, Shouakar-Stash O, El-Shiekh A, Parker B (2016) Geophysical and geochemical studies to delineate seawater intrusion in Bagoush area, northwestern coast, Egypt. J Afr Earth Sci 121:365-381

El Gayar A, Hamed Y (2017) Climate change and water resources management in Arab countries. Springer international publishing AG-Euro-Mediterranean and surrounding regions. Adv Sci Technol Innov. https://doi.org/10.1007/978-3-319-70548-4-31 
El Mandour A, El Yaouti F, Fakir Y, Zarhloule Y, Benavente J (2007) Evolution of groundwater salinity in the unconfined aquifer of bou-areg, Northeastern Mediterranean coast. Morocco Environ Geol 54:491-503

Ennabli M (1980) Étude hydrogéologique des aquifères du Nord-Est de la Tunisie pour une gestion intégrée des ressources en eau. Thesis $(\mathrm{PhD})$, University of Nice, France

Fadili A, Mehdi K, Riss J, Najib S, Makan A, Boutayab K (2015) Evaluation of groundwater mineralization processes and seawater intrusion extension in the coastal aquifer of Oualidia, Morocco: hydrochemical and geophysical approach. Arab J Geosci. https:// doi.org/10.1007/s12517-015-1808-5

Ferrara V, Pappalardo G (2004) Intensive exploitation effects on alluvial aquifer of the Catania plain, eastern Sicily, Italy. Geofisica Int 43:671-681

Gaaloul N, Cheng AH (2003) Hydrogeological and Hydrochemical Investigation of Coastal Aquifers in Tunisia-Crisis in Overexploitation and Salinization. In: Second International Conference on Saltwater Intrusion and Coastal Aquifers (p. 13)

Gaaloul N, Pliakas F, Kallioras A, Schuth C, Marinos P (2012) Simulation of seawater intrusion in coastal aquifers : forty five-years exploitation in an eastern coast aquifer in NE Tunisia, p 31-44

Giambastiani BMS, Colombani N, Mastrocicco M, Fidelibus MD (2013) Characterization of the lowland coastal aquifer of Comacchio (Ferrara, Italy): hydrology, hydrochemistry and evolution of the system. J Hydrol 501:35-44

Goebel M, Pidlisecky A, Knight R (2017) Resistivity imaging reveals complex pattern of saltwater intrusion along Monterey coast. J Hydrol 551:746-755

Hamed Y, Hadji R, Redhaounia B, Zighmi K, Bâali F, El Gayar A (2018) Climate impact on surface and groundwater in North Africa-a global synthesis of findings and recommendations. Euro-Mediterranean J Environ Integr. https://doi.org/10.1007/ s41207-018-0059-8

Kazakis N, Pavlou A, Vargemezis G, Voudouris KS, Soulios G, Pliakas F, Tsokas G (2016) Seawater intrusion mapping using electrical resistivity tomography and hydrochemical data. An application in the coastal area of eastern Thermaikos Gulf, Greece. Sci Total Environ 543:373-387

Kerrou J (2008) Deterministic and probabilistic numerical modeling towards sustainable groundwater management: application to seawater intrusion in the Korba aquifer (Tunisia). Centre of Hydrogeology of the University of Neuchâtel, Stochastic hydrogeology Group. PhD Thesis, $\mathrm{p} 181$

Kiberu J (2002) Induced polarization and resistivity measurements on a suite of near surface soil samples and their empirical relationship to selected measured engineering parameters, Thesis for the degree in Master of Science in. Appl Geophys. 19-31

Kouzana L, Ben Mammou A, Sfar M (2009) Seawater intrusion and associated processes: case of the Korba aquifer (Cap-Bon, Tunisia). C R Geosci 341:21-35

Kouzana L, Benassi R, Ben Mammou A, Sfar M (2010) Journal of African earth sciences geophysical and hydrochemical study of the seawater intrusion in Mediterranean semi arid zones. Case of the Korba coastal aquifer (Cap-Bon, Tunisia). J Afr Earth Sc 58(2):242-254

Lambrakis NJ, Voudouris KS, Tiniakos LN, Kallergis G (1997) Impact of simultaneous action of drought and over pumping on quaternary aquifers of Glafkos basin (Patras region, western Greece). Environ Geol 29:209-215

Lecca G, Khlaifi I, Tarhouni J, Paniconi C (1998) Modeling seawater intrusion in the Korba aquifer (Tunisia). Trans Ecol Environ 17:209-217

Loke MH, Barker RD (1996) Practical techniques for 3D resistivity surveys and data inversion. Geophys Prospect 44:499-523
Maillet GM, Rizzo E, Revil A, Vella C (2005) High resolution electrical resistivity tomography (ERT) in a transition zone environment: application for detailed internal architecture and infilling processes study of a rhône river paleochannel. Mar Geophys Res $26: 317-328$

Mario Z, Joan B, Rogelio L, Xavier MP (2011) Electrical methods (VES and ERT) for identifying, mapping and monitoring different saline domains in a coastal plain region (Alt Emporda, Northern Spain). J Hydrol 409:407-422

Martinez J, Benavente J, Garcia-Arostegui JL, Hidalgo MC, Rey J (2009) Contribution of electrical resistivity tomography to the study of detrital aquifers affected by seawater intrusionextrusion effects: the river Vélez delta (Vélez-Málaga, southern Spain). Eng Geol 108:161-168

Martinez-Moreno FJ, Pedrera A, Ruano P, Galindo-Zaldivar J, Martos-Rosillo S, Gonzalez-Castillo L, Sanchez-Ubeda JP, MarinLechado C (2013) Combined microgravity, electrical resistivity tomography and induced polarization to detect deeply buried caves: algaidilla cave (Southern Spain). Eng Geol 162:67-78

Mcinnis D, Silliman S, Boukari M, Yalo N, Orou-pete S, Fertenbaugh C, Sarre K, Fayomi H (2013) Combined application of electrical resistivity and shallow groundwater sampling to assess salinity in a shallow coastal aquifer in Benin, West Africa. J Hydrol 505:335-345

Mekni A, Souissi A (2016) The effectiveness of artificial recharge by treated wastewater in combating seawater intrusion-The case study of Korba-El Mida aquifer (Cape Bon, Tunisia). IJIAS 15(2):264-274

Najib S, Fadili A, Mehdi K, Ris J, Makan A, Guessir H (2016) Salinization process and coastal groundwater quality in Chaouia, Morocco. J Afr Earth Sc 115:17-31

Najib S, Fadili A, Mehdi K, Riss J, Makan A (2017) Contribution of hydrochemical and geoelectrical approaches to investigate salinization process and seawater intrusion in the coastal aquifers of Chaouia. Morocco. J Contam Hydrol 198:24-36

Nowroozi AA, Stephen BH, Henderson P (1999) Saltwater intrusion into the freshwater aquifer in the eastern shore of Virginia: a reconnaissance electrical resistivity survey. J Appl Geophys 42:1-22

Omrane MN (2008) Eau, population et usage de l'eau potable dans le Cap-Bon- Approche cartographique et dynamique. Dynamiques Territoriales et développement dans le Gouvernorat de Nabeul. Unité de Recherche et Développement. Conseil Régional du Gouvernorat de Nabeul, Tunisia, pp 1-64

Paniconi C, Khlaifi I, Giuditta L, Giacomelli A, Tarhouni J (2001) Modeling and analysis of Seawater Intrusion in the coastal aquifer of eastern Cap-Bon, Tunisia, kluwer academic publishers, Netherlands. Trans Porous Media 43:3-28

Redhaounia B, Bedir M, Gabtni H, Batobo OI, Dhaoui M, Chabaane A, Khomsi S (2016) Hydro-geophysical characterization for groundwater resources potential of fractured limestone reservoirs in Amdoun Monts (North-western Tunisia). J Appl Geophys 128:150-162

Rey J, Martínez J, Barberá GG, García-Aróstegui JL, García-Pintado J, Martínez-Vicente D (2013) Geophysical characterization of the complex dynamics of groundwater and seawater exchange in a highly stressed aquifer system linked to a coastal lagoon (SE Spain). Environ Earth Sci 70:2271-2282

Sasaki K (1992) Two new and two resurrected species of the sciaenid genus Johnius (Johnius) from the West Pacific. Jap J Ichthyol 39(3):191-199

Sauret ESG, Beaujean J, Nguyen F, Wildemeersch S, Brouyere S (2015) Characterization of superficial deposits using electrical resistivity tomography (ERT) and horizontal-to-vertical spectral ratio (HVSR) geophysical methods : a case study. J Appl Geophys 121:140-148 
Tarhouni J, Jemai S, Walraevens K, Rekaya M (2000) Caractérisation de l'aquifère côtier de Korba au Cap-Bon (Tunisie). In: K. Walraevens (ed), Development of Water Resource Management Tools for Problems of Sea Water Intrusion and Contamination of Fresh-Water Resources in Coastal Aquifers. SWIMCA, EC Initiative AVICENNA AVI-CT95-73, Tunisia, p 11-27

Tarhouni J, Khlafii I, Ben Alaya A, Paniconi C (2002) Integration Method of GIS and model KODESA-3D for studying transport problem in Korba Aquifer. In: Proceedings of international symposium on environmental pollution control and waste management. Tunis (EPCOWM 2002), p 497-50

Tkachev AV, Khazanov IM, Mikhalitsyna TI (2017) Geological and geophysical interpretation of induced-polarization data on gold depoits in the Yana-Kolyma orogenic belt. Russ Geol Geophys 58:1426-1434

Werner AD, Bakker M, Post VEA, Vandenbohede A, Lu C, Ataieashtiani B, Simmons CT, Barry DA (2013) Advances in Water resources seawater intrusion processes, investigation and management : recent advances and future challenges. Adv Water Resour 51:3-26

Zarroca M, Bach J, Linares R, Pellicer XM (2011) Electrical methods (VES and ERT) for identifying, mapping and monitoring different saline domains in a coastal plain region (Alt Empordà, Northern Spain). J Hydrol 409:407-422

Zghibi A, Zouhri L, Tarhouni J (2011) Groundwater modelling and marine intrusion in the semi-arid systems (Cap-Bon, Tunisia). Hydrol Process 25:1822-1836

Zghibi A, Merzougui A, Zouhri L, Tarhouni J (2013) Interaction between groundwater and seawater in the coastal aquifer of CapBon in the semi-arid systems (north-east of Tunisia). Carbonates Evaporites 87:18

Zouhri L, Carlier E, Ben Kabbour B, Toto EA, Gorini C, Louche B (2008) Groundwater interaction in the coastal environment: hydrochemical, electrical and seismic approaches. Bull Eng Geol Environ $67: 123-128$ 